\title{
IL1A Gene
}

National Cancer Institute

\section{Source}

National Cancer Institute. IL1A Gene. NCI Thesaurus. Code C28592.

This gene plays a role in the mediation of inflammation and immunity. 